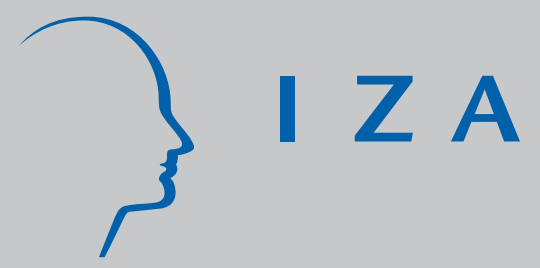

IZA DP No. 133

Paid and Unpaid Overtime Working in Germany and the UK

David N. F. Bell

Robert A. Hart

Olaf Hübler

Wolfgang Schwerdt

March 2000 


\title{
Paid and Unpaid Overtime Working in Germany and the UK
}

\author{
David N. F. Bell \\ University of Stirling \\ Robert A. Hart \\ University of Stirling and IZA, Bonn \\ Olaf Hübler \\ University of Hannover \\ Wolfgang Schwerdt \\ Université de Paris 1 and CREST
}

Discussion Paper No. 133
March 2000

\author{
IZA \\ P.O. Box 7240 \\ D-53072 Bonn \\ Germany \\ Tel.: +49-228-3894-0 \\ Fax: +49-228-3894-210 \\ Email: iza@iza.org
}

This Discussion Paper is issued within the framework of IZA's research area Mobility and Flexibility of Labor Markets. Any opinions expressed here are those of the author(s) and not those of the institute. Research disseminated by IZA may include views on policy, but the institute itself takes no institutional policy positions.

The Institute for the Study of Labor (IZA) in Bonn is a local and virtual international research center and a place of communication between science, politics and business. IZA is an independent, nonprofit limited liability company (Gesellschaft mit beschränkter Haftung) supported by the Deutsche Post AG. The center is associated with the University of Bonn and offers a stimulating research environment through its research networks, research support, and visitors and doctoral programs. IZA engages in (i) original and internationally competitive research in all fields of labor economics, (ii) development of policy concepts, and (iii) dissemination of research results and concepts to the interested public. The current research program deals with (1) mobility and flexibility of labor markets, (2) internationalization of labor markets and European integration, (3) the welfare state and labor markets, (4) labor markets in transition, (5) the future of work, (6) project evaluation and (7) general labor economics.

IZA Discussion Papers often represent preliminary work and are circulated to encourage discussion. Citation of such a paper should account for its provisional character. 


\section{ABSTRACT \\ Paid and Unpaid Overtime Working in Germany and the UK*}

Significant numbers of employees work more hours in the workplace than their contract stipulates. Such overtime work can either be paid or unpaid. This research considers overtime working in Germany and the UK and shows that the quantitative significance of both paid and unpaid overtime is greater in the UK. Empirical work is based on the UK Labour Force Survey and the German Socio-Economic Panel in 1993. Overtime influences the effective average hourly wage positively in the case where overtime is paid at premium rates and negatively where such hours are not remunerated. We demonstrate via Mincer wage growth equations that accounting for unpaid work leads to revised estimates of experience and tenure both within and between the two countries. We estimate overtime hours equations, using these to test several of our theories that might explain the apparent irrationality of unpaid work.

JEL Classification: J22, J23, J33

Keywords: Unpaid Overtime, hours determination, earnings effects

Robert A. Hart

Department of Economics

University of Stirling

Stirling FK9 4LA

Scotland, UK

Tel.: + 441786467471

Fax: + 441786467279

Email: r.a.hart@stir.ac.uk

\footnotetext{
* This work was financed by a grant from the Anglo-German Foundation. We thank participants at the Conference on Trade and Labour Market Adjustment, University of Nottingham, March 1999. We are also grateful to Elizabeth Roberts for research assistance.
} 


\section{INTRODUCTION}

In Germany, working time has featured prominently in recent years as a national employment policy issue. Similar European interest has also been displayed in France and Italy. In these relatively regulated labour markets, there has been a strong revival of support for the notion that cutting working hours may help to create new jobs for the unemployment. By contrast, Britain has been an almost lone European voice in urging that a minimum amount of regulation should cover the supply and demand of working hours. ${ }^{1}$ The role of overtime working is central to the European work sharing debates since this variable offers perhaps the greatest scope for reducing the availability of work to those with jobs and increasing job opportunities for the unemployed. There are potential problems associated with overtime reductions, however. One of these has recently been emphasised by Bauer and Zimmermann (1999) in the case of Germany. They show that unskilled workers experience relatively low overtime and the highest risks of becoming unemployment. By contrast, skilled workers undertake relatively high levels of overtime and face excess demand for their labour services. Since skilled and unskilled workers are largely

\footnotetext{
1 One reason for the difference between Germany and the UK has been their contrasting experience of the role of collective bargaining in relation to working time. In the UK, as a result of previous attempts to improve competitiveness, unions are relatively weak and there are virtually no legislative controls over working time. Hours agreements, both standard and overtime, tend to be reached at company level (see, for example, Income Data Services, 1997). In Germany, by contrast, it is estimated that about 73 per cent of the eligible workforce is covered by works councils (Addison et al., 1998) and there exists a legal framework setting working time standards that can only be modified by joint agreement between works councils and employers. Companies with five or more employees are expected to have a works council. Moreover, important working time issues in Germany, such as the length of the standard workweek, are negotiated between management and unions at industry level (Hunt, 1999).
} 
complements in production, reductions in overtime lead to less production and a decline in unskilled employment.

Here, we focus on a new, and highly significant, area of overtime working in the two economies that provides even greater potential problems for policy makers. This concerns the fact that workers in Germany and the UK undertake significant levels of both paid and unpaid overtime. ${ }^{2}$ The work sharing debate features paid overtime. It has completely ignored the fact that important elements of labour provide extra hours at no extra cost. This paper investigates the incidence and labour market implications of the phenomenon of unpaid overtime in the two economies.

Both German and UK workers undertake significant amounts of unpaid overtime hours. As with paid overtime, however, it is clear that British workers offer considerably higher levels of unpaid hours than their German counterparts. Two potential competitive advantages accrue to the UK's experience of relatively high levels of paid and unpaid overtime. First, the incidence and length of hours of paid/unpaid work signal significantly higher degrees of intensive margin flexibility. Second, unpaid hours serve to accentuate UK labour cost advantages over its European competitors because they reduce the effective hourly wage rate. This latter point is particularly explored here because it raises a quite general and fundamental labour market issue. Published hourly wages relate only to paid-for hours - i.e. basic

\footnotetext{
${ }^{2}$ Separate data on paid and unpaid overtime are only just emerging in European countries. Germany and the UK have been at the vanguard of providing comprehensive data on these two overtime elements. Earlier work on unpaid overtime is limited, although see Gerlach and Hübler (1987) and Bell and Hart (1999a).
} 
hours and paid overtime. The effective hourly wage rate should additionally take into account worked hours for which no remuneration is received.

The paper is based on matched German-UK data sets extracted from the German Socio-Economic Panel (SOEP) and the UK Labour Force Survey (LFS). It starts by discussing why certain individuals may agree to work some overtime hours without apparently being explicitly paid for their services. It then considers how Germany and the UK compare in respect of both forms of overtime working and related wage compensation. We show, in particular, that there can be substantial differences between basic and effective hourly rates when unpaid hours are accounted for. Pursuing this wage distinction, we proceed to investigate whether the returns to characteristics are different when one uses the alternative definitions of the hourly wage rate. We conclude the analytical sections by considering the factors that might influence paid and unpaid overtime working.

\section{REASONS FOR WORKING UNPAID OVERTIME}

Based on arguments set out in Bell and Hart (1999a), we advance six hypotheses concerning propensities to undertake unpaid overtime.

\section{Hypothesis 1. Unpaid overtime is associated with uncertainty over job task}

\section{completion times.}

Where job tasks are complex, more uncertainty may attach to the time required in order fully to execute the job than to the wage rate per period needed to hire someone with the requisite skills. The principal and agent may bargain not over the wage rate for the job but over the length of time the job will take, given the wage rate. The contract will have to satisfy the participation constraints of both parties, but as a result 
of the random noise associated with the time taken to complete any task, some workers may have to provide more labour than allowed for by the contract. Such a worker is effectively undertaking unpaid work. Two broad categories of (nonmutually exclusive) workers might be expected to experience relatively high degrees of uncertainty over the length of time required to complete job tasks. First, managers and professional workers undertake relatively complex jobs, the execution of which may require multi-task human capital and organisational skills. Second, non-union workers are less likely to undertake job tasks based on formalised work scheduling.

Hypothesis 2. Unpaid overtime is negatively associated with worker productivity. Some firms may find it advantageous to allow workers to compete in order to perform certain job tasks. This competition may take the form of an auction where workers bid to be allowed to undertake the work available. The bid takes the form of the length of time the employee estimates is necessary to complete the task. Less productive workers would find themselves at a competitive disadvantage if they bid honestly. However, so long as employers are indifferent to the hours that workers actually expend over the execution the task, such workers might win the auctions if they 'overbid' on time by providing additional unpaid-for hours.

Hypothesis 3. Workers with leadership roles work more unpaid overtime.

Many enterprises organise workers into teams with specific group-based productivity targets. Where some workers are occasionally absent or are less productive, team leaders may compensate by working additional unpaid hours. They do so because they will suffer a loss of reputation if targets are not met. Although not compensated at present, they may take the view that such additional effort may lead to greater reward in the future . 
Hypothesis 4. Unpaid work represents a form gift exchange.

Akerlof (1982) argues that social norms of behaviour may lead to workers and firms engaging in gift exchange. The value of the gift from the firm is the margin between the actual wage and the outside wage. The worker's gift is "work in excess of the minimum standard" (Akerlof, 1982, p.544). The efficiency wage literature has usually interpreted this as a higher level of per-hour productivity. But an alternative form for the workers' gift might be additional hours worked without any change in work intensity. These additional hours are in a sense unpaid because they are in excess of contractual hours. This outcome may be Pareto optimal for both workers and the firm so long as employers are indifferent to the number of hours actually worked. In this event, we might anticipate a relatively strong positive association between straighttime wage rates and unpaid work. Firms that compensate well, ceteris paribus, are likely to receive more unpaid work as a gift response from their workers.

Hypothesis 5. Unpaid overtime is associated with exogenous rules pertaining to paid overtime.

Legal constraints on paid-for working time and agreements set at a level above the individual enterprise may impose conditions different from those that would result from a standard bargaining framework. For example, a lower overtime premium may be Pareto optimal compared to one imposed externally. This could be achieved in the form of a compensating differential whereby workers agree to undertake a proportion of their overtime hours at the official rate and the remainder unofficially at a zero rate. Empirical work by Bell and Hart (1999a) lead to the rejection of this hypothesis for the UK. Unfortunately, it cannot be tested for Germany because the SOEP question 
on overtime is such that paid and unpaid overtime are assumed to be mutually exclusive.

Hypothesis 6. Unpaid overtime is negatively associated with unionised workforces. Unpaid work might represent exploitation of workers by monopsonistic employers. If this is the case then one might expect that its incidence would be lower in unionised workplaces.

We test some of these explanations of unpaid overtime using data for both Britain and Germany in Section 5.

\section{BACKGROUND}

Our study is based on matched data from the UK LFS and the German SOEP $^{3}$ for 1993. These surveys ask questions about both paid and unpaid overtime working. In this section, as background to our econometric estimates, we compare and contrast relevant features of these datasets.

\section{(a) Overtime hours}

Tables $1 \mathrm{a}$ and $1 \mathrm{~b}$ contain summary statistics from our combined data sets for males and females, respectively. Averaged across male workers, basic weekly hours for males in Germany are approximately 45 minutes greater than in the UK. The latter country exhibits much wider basic hours' variation; its standard deviation is over twice that of Germany. Basic weekly hours for UK females are nearly 4 hours lower than their German counterparts. Both countries display wide variation in female hours

\footnotetext{
${ }^{3}$ Brief details of these surveys are contained in the Appendix.
} 
although, again, the UK's standard deviation is larger than its German equivalent. This almost certainly reflects the greater incidence of part-time working in the UK. ${ }^{4}$

The overtime components of working time also display a number of significant differences between the two countries. Male paid-for overtime hours in the UK average 2.09 per week over all workers, while the equivalent German figure is only 0.98 hours. Paid and unpaid overtime comprise 9.9 per cent of the total hours input amongst males in the UK, but only 4 per cent in Germany. Averaged over all females, paid and unpaid overtime comprises 6.1 per cent of total hours input in the UK compared to only 1.5 per cent in Germany.

The incidences of paid overtime for males in Germany and the UK are broadly similar, at 19.8 and 21.6 per cent respectively. A much lower proportion of females undertake paid overtime in both countries, with the German and UK proportions again roughly comparable at 7.1 and 9.2 per cent respectively. Amongst those working paid overtime, UK males work an average of 9.7 hours a week, with German males working 5 hours. Even UK females that work paid overtime supply almost 28 per cent more than do German males each week.

While similar proportions of the workforce undertake paid overtime in the UK and Germany, much greater discrepancies occur with respect to unpaid overtime. More

\footnotetext{
${ }^{4}$ Participation rates among women are much higher in the UK. These higher rates exist in an environment where working hours vary much more widely.
} 
TABLE 1a: HOURS AND WAGES IN GERMANY AND THE UK

MALES - 1993

\begin{tabular}{|c|c|c|}
\hline & Germany & UK \\
\hline All Workers (sample size) & (1834) & $(1531)$ \\
\hline Basic Hours & $\begin{array}{c}38.02 \\
(2.97)^{*}\end{array}$ & $\begin{array}{l}37.15 \\
(7.09)\end{array}$ \\
\hline Paid Overtime Hours & $\begin{array}{c}0.98 \\
(2.86)\end{array}$ & $\begin{array}{c}2.09 \\
(5.22)\end{array}$ \\
\hline Unpaid Overtime Hours & $\begin{array}{c}0.59 \\
(2.50)\end{array}$ & $\begin{array}{c}1.98 \\
(4.84)\end{array}$ \\
\hline Basic Hourly Wage Rate (BHR)** & $\begin{array}{l}14.11 \\
(6.57)\end{array}$ & $\begin{array}{c}8.43 \\
(5.73)\end{array}$ \\
\hline Effectively Hourly Wage Rate (EHR) & $\begin{array}{l}13.90 \\
(6.08)\end{array}$ & $\begin{array}{c}7.99 \\
(5.06)\end{array}$ \\
\hline Proportion Working Paid Overtime & $19.8 \%$ & $21.6 \%$ \\
\hline Proportion Working Unpaid Overtime & $9.2 \%$ & $23.4 \%$ \\
\hline Proportion Working Overtime & $29.0 \%$ & $45.1 \%$ \\
\hline Working Paid Overtime (sample size) & $(363)$ & $(331)$ \\
\hline Basic Hours & $\begin{array}{l}38.45 \\
(2.79)\end{array}$ & $\begin{array}{l}37.55 \\
(6.44)\end{array}$ \\
\hline Paid Overtime Hours & $\begin{array}{c}4.95 \\
(4.66)\end{array}$ & $\begin{array}{c}9.68 \\
(7.25)\end{array}$ \\
\hline Basic Hourly Wage Rate (BHR) & $\begin{array}{l}12.63 \\
(4.53)\end{array}$ & $\begin{array}{c}5.78 \\
(2.20)\end{array}$ \\
\hline Effectively Hourly Wage Rate (EHR) & $\begin{array}{l}13.06 \\
(4.70)\end{array}$ & $\begin{array}{c}6.21 \\
(2.36)\end{array}$ \\
\hline Working Unpaid Overtime (sample size) & $(169)$ & $(359)$ \\
\hline Basic Hours & $\begin{array}{l}38.06 \\
(3.27)\end{array}$ & $\begin{array}{l}37.67 \\
(4.45)\end{array}$ \\
\hline Unpaid Overtime Hours & $\begin{array}{c}6.42 \\
(5.51)\end{array}$ & $\begin{array}{c}8.46 \\
(6.73)\end{array}$ \\
\hline Basic Hourly Wage Rate (BHR) & $\begin{array}{l}23.06 \\
(8.70)\end{array}$ & $\begin{array}{l}12.27 \\
(6.51)\end{array}$ \\
\hline Effectively Hourly Wage Rate (EHR) & $\begin{array}{l}19.92 \\
(7.35)\end{array}$ & $\begin{array}{c}9.98 \\
(5.09)\end{array}$ \\
\hline
\end{tabular}

* Standard deviations in parentheses under means

** All wage rates are expressed in ECUs and converted at the average rate of exchange for 1993. 
TABLE 1b: HOURS AND WAGES IN GERMANY AND THE UK

FEMALES - 1993 *

\begin{tabular}{|c|c|c|}
\hline & Germany & UK \\
\hline All Workers (sample size) & $(1393)$ & $(1528)$ \\
\hline Basic Hours & $\begin{array}{l}32.40 \\
(9.36)\end{array}$ & $\begin{array}{c}28.53 \\
(11.38)\end{array}$ \\
\hline Paid Overtime Hours & $\begin{array}{c}0.27 \\
(1.24)\end{array}$ & $\begin{array}{c}0.59 \\
(2.39)\end{array}$ \\
\hline Unpaid Overtime Hours & $\begin{array}{c}0.20 \\
(1.24)\end{array}$ & $\begin{array}{c}1.26 \\
(3.76)\end{array}$ \\
\hline Basic Hourly Wage Rate (BHR) & $\begin{array}{l}10.59 \\
(5.25)\end{array}$ & $\begin{array}{c}6.62 \\
(12.38)\end{array}$ \\
\hline Effectively Hourly Wage Rate (EHR) & $\begin{array}{l}10.54 \\
(5.16)\end{array}$ & $\begin{array}{c}6.33 \\
(12.27)\end{array}$ \\
\hline Proportion Working Paid Overtime & $7.1 \%$ & $9.2 \%$ \\
\hline Proportion Working Unpaid Overtime & $5.3 \%$ & $20.1 \%$ \\
\hline Proportion Working Overtime & $12.4 \%$ & $29.3 \%$ \\
\hline Working Paid Overtime (sample size) & (99) & $(141)$ \\
\hline Basic Hours & $\begin{array}{l}30.19 \\
(9.97)\end{array}$ & $\begin{array}{c}28.60 \\
(10.81)\end{array}$ \\
\hline Paid Overtime Hours & $\begin{array}{c}3.80 \\
(2.86)\end{array}$ & $\begin{array}{c}6.36 \\
(5.02)\end{array}$ \\
\hline Basic Hourly Wage Rate (BHR) & $\begin{array}{c}9.24 \\
(3.26)\end{array}$ & $\begin{array}{c}4.67 \\
(2.13)\end{array}$ \\
\hline Effectively Hourly Wage Rate (EHR) & $\begin{array}{c}9.56 \\
(3.35)\end{array}$ & $\begin{array}{c}4.99 \\
(2.26)\end{array}$ \\
\hline Working Unpaid Overtime (sample size) & (74) & $(307)$ \\
\hline Normal Hours & $\begin{array}{l}35.11 \\
(8.26)\end{array}$ & $\begin{array}{l}32.46 \\
(8.83)\end{array}$ \\
\hline Unpaid Overtime Hours & $\begin{array}{c}3.78 \\
(3.98)\end{array}$ & $\begin{array}{c}6.25 \\
(6.27)\end{array}$ \\
\hline Basic Hourly Wage Rate (BHR) & $\begin{array}{l}13.17 \\
(8.59)\end{array}$ & $\begin{array}{c}8.83 \\
(4.10)\end{array}$ \\
\hline Effectively Hourly Wage Rate (EHR) & $\begin{array}{l}11.90 \\
(7.84)\end{array}$ & $\begin{array}{c}7.28 \\
(3.01) \\
\end{array}$ \\
\hline
\end{tabular}

* See notes to Table 1a. 
than twice as many males and four times as many females in the UK claim to work non-contractual unpaid hours compared to their German equivalents. Males in the UK who work unpaid overtime claim to supply an average of 8.5 hours per week, while Germans work 6.4 hours. German females work 3.8 hours unpaid overtime, whereas their UK counterparts supply 6.3 hours per week.

\section{(b) Wages}

How does overtime working affect hourly pay? Introducing working hours in addition to those stipulated in the employment contract implies that one can define hourly pay in two different ways. The first is the basic hourly rate (BHR), which excludes the effects of overtime. The second is the effective hourly rate (EHR) which is calculated by averaging gross weekly pay over standard hours and overtime hours, whether these were paid for or not.

The BHR is defined as

$$
\begin{aligned}
B H R & =\frac{e}{\bar{h}+1.39 o_{p}} \text { if } o_{p}>0 \text { and country }=\mathrm{UK} \\
& =\frac{e}{\bar{h}+1.32 o_{p}} \text { if } o_{p}>0 \text { and country = Germany } \\
& =\frac{e}{\bar{h}} \text { otherwise }
\end{aligned}
$$

where $e$ is weekly gross earnings, $\bar{h}$ is standard hours, $o_{p}$ is paid overtime hours and $o_{u}$ is unpaid overtime hours. BHR defines the rate at which an individual is paid for the basic hours that they are contractually obliged to provide. To calculate these, we 
require to correct for the overtime premium that the individual receives for working any paid overtime. ${ }^{5}$

The EHR is simply the average hourly rate for all working hours - whether basic, paid overtime or unpaid overtime - and is defined

$$
\begin{aligned}
E H R & =\frac{e}{\bar{h}+o_{u}} \text { if } o_{u}>0 \\
& =\frac{e}{\bar{h}+o_{p}} \text { if } o_{p}>0 \\
& =\frac{e}{\bar{h}} \text { otherwise. }
\end{aligned}
$$

Most studies of inequality are concerned with income measures that indicate the command over resources conferred on a particular household or individual. However, from other labour market and social perspectives - such as incentive payments or gift exchange - it is arguable that the EHR more accurately reflects hourly wage differentials.

From the information on these earnings measures in Tables 1a and 1b, both BHR and EHR indicate higher rates of pay in Germany compared to the UK and for men

\footnotetext{
${ }^{5}$ In order to make adjustments for the premium rate, we used mean estimates for the UK derived in Bell and Hart (1999b) while for Germany the mean premium was derived from a dataset created by Wolfgang Meyer ( Bulmahn and Meyer, 1998). In the wage regressions that follow, we re-estimated BHR using a range of other values (between 1.2 and 1.5) obtaining relatively minor changes in the overall results. For a range of estimates of the overtime premium throughout the OECD see OECD Employment Outlook, 1998 and the discussion in Contensou and Vranceanu (1999).
} 
compared with women. They also show the differential effects on hourly earnings of paid and unpaid overtime. Working paid overtime tends to increase the EHR above the BHR, whereas unpaid overtime pulls the EHR below the BHR. The BHR of those working paid overtime is substantially less than for those working unpaid overtime.

We now consider the distribution of overtime working across three major occupational groups within Germany and the UK. In Table 2 we give information on (i) managers, (ii) professionals and (iii) craft, plant and machine operatives.

Consistent with hypothesis 1 in Section 2, the incidence and hours of unpaid overtime is especially quantitatively important among managers and professionals. While managers in Germany appear to work more unpaid overtime hours than their counterparts in the UK, we note that the German definition of 'manager' accounts for only 2.6 of the workforce in Germany, compared with 20.3 per cent under the UK definition. It is almost certainly the case that the German definition of manager embraces a narrower and more senior job description. Amongst professionals, who comprise 24.6 per cent and 15.4 per cent of the workforce in the UK and Germany respectively, unpaid overtime working is much more prevalent in the UK. Among British professional workers, 16 per cent of males and 14 per cent of females claim to work more than 6 hours unpaid overtime per week. In contrast, only 5.4 per cent of professional males and 1.9 per cent of professional females in Germany provide more than 6 hours unpaid overtime per week. The incidences and levels of paid overtime among managers and professionals in both countries are well below comparable unpaid work. In stark contrast, very few craft, plant and machine operatives claim to work unpaid overtime in either the UK or Germany while their incidence and hours of paid overtime are considerably greater than among managers and professionals. This 
TABle 2: PAID AND UNPaId OVERTIME Hours by OCCUPATION

\begin{tabular}{|c|c|c|c|c|c|c|c|c|c|c|c|c|}
\hline \multirow[b]{2}{*}{ Hours of Overtime } & \multicolumn{5}{|c|}{ Percent working unpaid overtime } & \multicolumn{5}{|c|}{ Percent working paid overtime } & \multirow[b]{2}{*}{ No. } & \multirow[b]{2}{*}{ Percent } \\
\hline & $\mathbf{0}$ & 1-6 & $7-12$ & 13-20 & 21-40 & $\mathbf{0}$ & $1-6$ & $7-12$ & $13-20$ & $21-40$ & & \\
\hline $\begin{array}{l}\text { U.K. Males } \\
\text { Managers and Administrators } \\
\text { Professional } \\
\text { Craft, plant and machine } \\
\text { operatives }\end{array}$ & $\begin{array}{l}51.3 \\
65.5 \\
97.1\end{array}$ & $\begin{array}{c}21.6 \\
18.3 \\
1.8\end{array}$ & $\begin{array}{l}16.5 \\
8.2 \\
0.9\end{array}$ & $\begin{array}{l}8.4 \\
5.0 \\
0.0\end{array}$ & $\begin{array}{l}2.3 \\
2.9 \\
0.2\end{array}$ & $\begin{array}{l}95.5 \\
89.4 \\
57.3\end{array}$ & $\begin{array}{c}2.6 \\
5.3 \\
15.0\end{array}$ & $\begin{array}{c}1.0 \\
3.5 \\
16.6\end{array}$ & $\begin{array}{l}0.7 \\
0.5 \\
7.3\end{array}$ & $\begin{array}{l}0.3 \\
1.3 \\
3.9\end{array}$ & $\begin{array}{l}310 \\
377 \\
440\end{array}$ & $\begin{array}{l}20.3 \\
24.6 \\
28.7\end{array}$ \\
\hline \multicolumn{13}{|l|}{ Germany Males } \\
\hline $\begin{array}{l}\text { Managers and Administrators } \\
\text { Professional } \\
\text { Craft, plant and machine } \\
\text { operatives }\end{array}$ & $\begin{array}{l}45.8 \\
77.2 \\
98.8\end{array}$ & $\begin{array}{c}20.8 \\
17.4 \\
0.7\end{array}$ & $\begin{array}{c}14.6 \\
4.3 \\
0.3\end{array}$ & $\begin{array}{l}12.5 \\
0.7 \\
0.2\end{array}$ & $\begin{array}{c}6.3 \\
0.4 \\
0\end{array}$ & $\begin{array}{l}83.3 \\
89.7 \\
71.8\end{array}$ & $\begin{array}{c}4.2 \\
8.2 \\
21.4\end{array}$ & $\begin{array}{c}12.5 \\
1.8 \\
5.1\end{array}$ & $\begin{array}{c}0 \\
0 \\
0.8\end{array}$ & $\begin{array}{c}0 \\
0.4 \\
0.9\end{array}$ & $\begin{array}{c}48 \\
281 \\
967\end{array}$ & $\begin{array}{c}2.6 \\
15.4 \\
52.9\end{array}$ \\
\hline $\begin{array}{l}\text { UK Females } \\
\text { Managers and Administrators } \\
\text { Professional } \\
\text { Craft, plant and machine } \\
\text { operatives } \\
\end{array}$ & $\begin{array}{l}59.6 \\
62.7 \\
94.2\end{array}$ & $\begin{array}{c}27.6 \\
23.3 \\
4.4\end{array}$ & $\begin{array}{c}7.1 \\
6.9 \\
0\end{array}$ & $\begin{array}{c}3.9 \\
5.4 \\
0\end{array}$ & $\begin{array}{l}1.9 \\
1.7 \\
1.5\end{array}$ & $\begin{array}{l}96.2 \\
93.1 \\
82.6\end{array}$ & $\begin{array}{l}2.6 \\
3.2 \\
8.7\end{array}$ & $\begin{array}{l}1.3 \\
2.0 \\
5.8\end{array}$ & $\begin{array}{c}0 \\
1.5 \\
2.9\end{array}$ & $\begin{array}{c}0 \\
0.3 \\
0\end{array}$ & $\begin{array}{c}156 \\
407 \\
69\end{array}$ & $\begin{array}{c}10.2 \\
26.7 \\
4.5\end{array}$ \\
\hline $\begin{array}{l}\text { Germany Females } \\
\text { Managers and Administrators } \\
\text { Professional } \\
\text { Craft, plant and machine } \\
\text { operatives }\end{array}$ & $\begin{array}{c}82.4 \\
91.4 \\
100\end{array}$ & $\begin{array}{c}17.7 \\
6.7 \\
0\end{array}$ & $\begin{array}{c}0 \\
1.4 \\
0\end{array}$ & $\begin{array}{l}0 \\
0 \\
0\end{array}$ & $\begin{array}{c}0 \\
0.5 \\
0\end{array}$ & $\begin{array}{l}94.1 \\
97.1 \\
91.8\end{array}$ & $\begin{array}{c}0 \\
1.0 \\
7.2\end{array}$ & $\begin{array}{l}5.9 \\
1.9 \\
1.0\end{array}$ & $\begin{array}{l}0 \\
0 \\
0\end{array}$ & $\begin{array}{l}0 \\
0 \\
0\end{array}$ & $\begin{array}{c}17 \\
210 \\
208\end{array}$ & $\begin{array}{c}1.2 \\
15.2 \\
15.0\end{array}$ \\
\hline
\end{tabular}


TABLE 3: Basic ANd EfFective Wage Earnings by Three OCCUPATIONS

\begin{tabular}{|l|c|c|c|c|c|c|}
\hline \multicolumn{3}{|c|}{ U.K. } & \multicolumn{3}{c|}{ Germany } \\
\hline Males & BHR & EHR & $\begin{array}{c}\text { EHR/BHR } \\
(\%)\end{array}$ & BHR & EHR & $\begin{array}{c}\text { EHR/BHR } \\
(\%)\end{array}$ \\
\hline Managers and administrators & 12.3 & 11.0 & 89.4 & 25.0 & 22.0 & 88.0 \\
\hline Professional & 10.4 & 9.7 & 93.3 & 20.8 & 20.2 & 97.1 \\
\hline $\begin{array}{l}\text { Craft, plant and machine } \\
\text { operatives }\end{array}$ & 5.9 & 6.1 & 103.4 & 11.7 & 11.8 & 100.9 \\
\hline Females & BHR & EHR & $\begin{array}{c}\text { EHR/BHR } \\
(\%)\end{array}$ & BHR & EHR & $\begin{array}{c}\text { EHR/BHR } \\
(\%)\end{array}$ \\
\hline Managers and administrators & 7.3 & 6.8 & 93.2 & 17.4 & 16.9 & 97.1 \\
\hline Professional & 9.4 & 8.7 & 92.6 & 14.8 & 14.6 & 98.8 \\
\hline $\begin{array}{l}\text { Craft, plant and machine } \\
\text { operatives }\end{array}$ & 4.4 & 4.4 & 100.0 & 9.1 & 9.1 & 100.2 \\
\hline
\end{tabular}

is particularly true for males, where 42.6 per cent work paid overtime, compared with 28.2 per cent in Germany.

As would be expected from the foregoing data on unpaid work, managers and professionals in both countries exhibit quite considerable EHR - BHR differentials. More importantly for our purposes there are smaller differentials between basic and effective hourly rates in Germany compared to the UK. The EHR of male managers in Germany and the UK is more than 10 per cent below the BHR. Amongst females, the differentials among managers and professionals are more marked than among their German equivalents. In the following section, we explain the relative performances of these two different wage variables in more detail. 


\section{EFFECTS OF UNPAID OVERTIME ON RETURNS TO CHARACTERISTICS}

From the previous section, it is clear that overtime working differentially affects workers' EHRs. In this section, we examine how the inclusion or exclusion of overtime working in the definition of the hourly wage rate affects the determinants of hourly wages. We use a standard Mincer equation to determine whether returns to tenure, experience and schooling are affected by the choice between effective and basic hourly wage rates as dependent variable. The form of the estimating equation is:

$$
\ln (w)=a_{0}+\mathbf{c}^{\prime} \mathbf{x}+\varepsilon
$$

where $\ln (\mathrm{w})$ is the logarithm of either BHR or EHR, $\mathbf{c}$ is a vector of coefficients, $\mathbf{x}$ is a vector of explanatory variables and $\varepsilon$ is a disturbance term. Specifically, $\mathbf{x}$ consists of experience, tenure, years of schooling, marital status, firm size, and industry. Conditional on participation, the expected wage depends on the $\mathbf{x}$ variables in (3). It also depends on $\beta \lambda(\alpha)$ with $\lambda(\alpha)=\phi\left(\mathbf{g}^{\prime} \mathbf{v} / \sigma\right) / \Phi\left(\mathbf{g}^{\prime} \mathbf{v} / \sigma\right)$ (i.e. the inverse Mills' ratio), where $\Phi$ is the cumulative function of a standard normal random variable and $\phi$ is its density function, and where $\mathbf{g}$ is a vector of coefficients, $\mathbf{v}$ the vector of variables from the selection equation and $\sigma$ the variance of the disturbance term of this equation. ${ }^{6}$

We obtained two-step Heckman estimates of equation (3) separately for males and females (Heckman, 1979). Therefore, there are four sets of results to take account both of gender and the definitions of the hourly wage rate. Our dataset is pooled over

\footnotetext{
${ }^{6}$ In the results that follow, we do not show the results for probit wage selection equation.
} 
Germany and the UK and is designed to reflect the relative size of their respective labour forces. ${ }^{7}$ To take account of possible inter-country differences, we include interactive dummies in our specifications. Given possible heterogeneity in the other factors influencing the distribution of earnings in both countries, we also make allowance for a form of group-wise heteroskedasticity in our estimates. The disturbance distribution is specified

$$
\begin{aligned}
u_{i} & \sim N\left(0, \sigma^{2}\right) \forall i \ni \text { Germany } \\
& \sim N\left(0, \mu \sigma^{2}\right) \forall i \ni U K .
\end{aligned}
$$

We then form maximum likelihood estimators of $\ell\left(w, x ; \beta, \sigma^{2}, \mu\right)$ and $\ell\left(w, x ; \beta, \sigma^{2}\right)$ where a likelihood-ratio test of the null $H_{o}: \mu=1$ provides a test for the equality of the variances of the disturbance across countries.

Results are shown in Tables 4 and 5 for males and females respectively. For both males and females, our estimates of $\mu$ in (4) reveal that earnings' dispersions are greater in the UK than in Germany. In fact, separate German and UK earnings regressions produced standard errors with UK/German ratios closely in line with our $\mu$ -estimates. Clearly, it is necessary to take account of this source of heteroskedasticity.

Returns to experience and tenure are modelled using quartic functions (Murphy and Welch, 1990). Their signs follow a pattern that is consistent with wages increasing

\footnotetext{
${ }^{7}$ This required taking a random sample of observations from the LFS, which is much the larger of the two surveys.
} 
with the acquisition of both general and specific human capital, but at a decreasing rate. The size and significance of the interactive terms suggest significantly greater returns to general experience in Germany. Comparisons of BHR and EHR returns to tenure and experience for the UK and Germany are shown in the simulated profiles presented in Tables 6 and 7 for males and females, respectively. The returns are based on an individual with 12 years of schooling who accumulates experience and tenure at the same rate over a 20 - year working period. As we would expect, returns generally are larger in Germany than the UK. Of course this in part reflects simply that German workers enjoy higher hourly rates of pay. Differences in institutional arrangements may also be reflected in the differential returns to characteristics. For example, returns to an additional year of schooling between the UK and Germany may be indicative of the considerable differences in the educational systems. Contrasting returns to tenure may depend on differing organisational structures within enterprises.

In addition to differences in returns between countries in Tables 6 and 7, it is clear that there are differential returns when the dependent variable is the effective hourly wage rate rather than the equivalent for the basic hourly rate. The results with respect to German males and females are quite marginal, however; throughout the simulation period, EHR is only slightly below its BHR equivalent. In the UK, these effects are far more marked for both genders, with EHR lying between 5 and 10 per cent below BHR. Overall, the net effect of paid and unpaid overtime is to reduce returns to tenure and experience by a greater amount in the UK compared to Germany. Therefore, 
TABle 4 Male Earnings Equations

(Heckman's two-step procedure)

\begin{tabular}{|c|c|c|c|c|}
\hline \multirow{2}{*}{$\frac{\text { Equation }}{\text { Variable }}$} & \multicolumn{2}{|c|}{ BHR } & \multicolumn{2}{|c|}{ HER } \\
\hline & Coefficient & t-statistic & Coefficient & t-statistic \\
\hline Experience & 0.068 & 4.902 & 0.064 & 4.782 \\
\hline Experience $^{2}$ & -0.002 & -2.066 & -0.002 & -2.063 \\
\hline Experience $^{3} * 10^{-2}$ & 0.004 & 1.022 & 0.004 & 1.043 \\
\hline Experience $^{4} * 10^{-4}$ & -0.003 & -0.711 & -0.003 & -0.742 \\
\hline Tenure & 0.047 & 3.398 & 0.053 & 3.990 \\
\hline Tenure $^{2}$ & -0.004 & -2.497 & -0.005 & -2.985 \\
\hline Tenure $^{3} * 10^{-2}$ & 0.015 & 2.123 & 0.017 & 2.509 \\
\hline Tenure $^{4} * 10^{-4}$ & -0.017 & -1.853 & -0.019 & -2.151 \\
\hline Germany*experience & 0.173 & 3.783 & 0.078 & 4.154 \\
\hline Germany*experience $^{2}$ & -0.005 & -3.102 & -0.005 & -3.343 \\
\hline Germany $^{*}$ experience ${ }^{3} * 10^{-2}$ & 0.011 & 2.309 & 0.011 & 2.469 \\
\hline Germany*experience ${ }^{4} * 10^{-4}$ & -0.008 & -1.675 & -0.008 & -1.795 \\
\hline Germany*tenure & 0.002 & 0.112 & -0.002 & -0.108 \\
\hline Germany*tenure $^{2}$ & -0.0004 & -0.253 & 0.00002 & 0.009 \\
\hline Germany $^{*}$ tenure ${ }^{3} * 10^{-2}$ & 0.001 & 0.130 & -0.001 & -0.102 \\
\hline Germany*tenure ${ }^{4} * 10^{-4}$ & 0.0001 & -0.013 & 0.002 & 0.176 \\
\hline Duration of Education & 0.081 & 15.909 & 0.070 & 14.368 \\
\hline Germany*Duration of Education & -0.028 & -4.536 & -0.021 & -3.573 \\
\hline Company Size & 0.229 & 7.634 & 0.221 & 7.659 \\
\hline Germany*Company Size & -0.090 & -2.408 & -0.077 & -2.141 \\
\hline Marital status & 0.242 & 4.628 & 0.254 & 4.968 \\
\hline Germany*Marital status & 0.228 & 3.178 & 0.235 & 3.328 \\
\hline Managerial status & 0.165 & 6.518 & 0.118 & 4.864 \\
\hline Germany*Managerial status & 0.095 & 2.876 & 0.106 & 3.303 \\
\hline Mills & 0.553 & 3.406 & 0.583 & 3.630 \\
\hline Constant & 0.026 & 0.244 & 0.054 & 0.505 \\
\hline$\mu$ & 2.112 & 20.423 & 1.996 & 20.423 \\
\hline Number of observations & 3364 & & 3364 & \\
\hline $\mathrm{F}(43,3320)$ & 135.07 & & 136.87 & \\
\hline R-squared & 0.636 & & 0.639 & \\
\hline Adj. R-squared & 0.632 & & 0.635 & \\
\hline Root MSE & 0.387 & & 0.376 & \\
\hline Log Likelihood & 1653.888 & & 1743.695 & \\
\hline
\end{tabular}

Note: Industry controls are included in the regressions, but their estimated coefficients are not shown. 
Table 5 Female Earnings Equations

(Heckman's two-step procedure)

\begin{tabular}{|c|c|c|c|c|}
\hline \multirow[b]{2}{*}{ Variable } & \multicolumn{2}{|c|}{ BHR } & \multicolumn{2}{|c|}{ HER } \\
\hline & Coefficient & t-statistic & Coefficient & t-statistic \\
\hline Experience & 0.050 & 3.426 & 0.050 & 3.531 \\
\hline Experience $^{2}$ & -0.002 & -1.690 & -0.002 & -1.867 \\
\hline Experience $^{3} * 10^{-2}$ & 0.004 & 0.947 & 0.005 & 1.096 \\
\hline Experience $^{4} * 10^{-4}$ & -0.003 & -0.560 & -0.003 & -0.676 \\
\hline Tenure & 0.042 & 3.036 & 0.039 & 2.878 \\
\hline Tenure $^{2}$ & -0.003 & -1.593 & -0.003 & -1.455 \\
\hline Tenure $^{3} * 10^{-2}$ & 0.012 & 1.290 & 0.011 & 1.184 \\
\hline Tenure $^{4} * 10^{-4}$ & -0.016 & -1.210 & -0.014 & -1.118 \\
\hline Germany*experience & 0.098 & 4.465 & 0.098 & 4.507 \\
\hline Germany*experience $^{2}$ & -0.006 & -3.068 & -0.005 & -3.006 \\
\hline Germany*experience $^{3} * 10^{-2}$ & 0.013 & 2.205 & 0.013 & 2.142 \\
\hline Germany*experience $^{4} * 10^{-4}$ & -0.011 & -1.670 & -0.010 & -1.618 \\
\hline Germany*tenure & -0.00009 & -0.004 & 0.002 & 0.106 \\
\hline Germany*tenure $^{2}$ & -0.001 & -0.432 & -0.002 & -0.534 \\
\hline Germany*tenure $^{3} * 10^{-2}$ & 0.006 & 0.462 & 0.008 & 0.551 \\
\hline Germany $^{*}$ tenure ${ }^{4} * 10^{-4}$ & -0.008 & -0.406 & -0.010 & -0.489 \\
\hline Duration of Education & 0.105 & 18.778 & 0.089 & 16.349 \\
\hline Germany*Duration of Education & -0.043 & -6.102 & -0.028 & -4.028 \\
\hline Company Size & 0.217 & 8.474 & 0.225 & 9.027 \\
\hline Germany*Company Size & 0.021 & 0.590 & 0.016 & 0.454 \\
\hline Marital status & -0.036 & -0.608 & -0.042 & -0.717 \\
\hline Germany*Marital status & 0.116 & 1.487 & 0.127 & 1.628 \\
\hline Managerial status & 0.174 & 6.646 & 0.152 & 5.970 \\
\hline Germany*Managerial status & 0.062 & 1.184 & 0.076 & 1.475 \\
\hline Mills & -0.195 & -0.729 & -0.209 & -0.781 \\
\hline Constant & 0.375 & 1.795 & 0.394 & 1.888 \\
\hline$\mu$ & 1.379 & 19.079 & 1.309 & 19.079 \\
\hline Number of observations & 2919 & & 2919 & \\
\hline $\mathrm{F}(43,2875)$ & 78.77 & & 79.49 & \\
\hline R-squared & 0.541 & & 0.543 & \\
\hline Adj. R-squared & 0.534 & & 0.536 & \\
\hline Root MSE & 0.416 & & 0.410 & \\
\hline Log Likelihood & 1138.321 & & 1177.411 & \\
\hline
\end{tabular}

Note: Industry controls are included in the regressions, but their estimated coefficients are not shown. 
Table 6 Simulated earnings profile for male workers with 12 years of schooling (ECU's)

\begin{tabular}{|c|c|c|c|c|c|}
\hline & \multicolumn{5}{|c|}{ Years } \\
\hline & 0 & 5 & 10 & 15 & 20 \\
\hline UK & & & & & \\
\hline BHR & 8.433 & 13.107 & 16.672 & 18.912 & 20.389 \\
\hline EHR & 7.989 & 12.419 & 15.584 & 17.365 & 18.447 \\
\hline$\%$ diff & 5.266 & 5.250 & 6.525 & 8.178 & 9.522 \\
\hline Germany & & & & & \\
\hline BHR & 14.106 & 28.108 & 39.024 & 43.312 & 43.187 \\
\hline EHR & 13.900 & 27.991 & 38.972 & 43.143 & 42.782 \\
\hline$\%$ diff & 1.459 & 0.416 & 0.133 & 0.390 & 0.939 \\
\hline
\end{tabular}

Table 7 Simulated earnings profile for female workers with 12 years of schooling (ECU's)

\begin{tabular}{|c|c|c|c|c|c|}
\hline & \multicolumn{5}{|c|}{ Years } \\
\hline & 0 & 5 & 10 & 15 & 20 \\
\hline UK & & & & & \\
\hline BHR & 6.615 & 9.454 & 11.514 & 12.858 & 13.838 \\
\hline EHR & 6.333 & 8.949 & 10.817 & 12.003 & 12.833 \\
\hline$\%$ diff & 4.264 & 5.347 & 6.054 & 6.652 & 7.264 \\
\hline Germany & & & & & \\
\hline BHR & 10.589 & 21.065 & 29.313 & 33.366 & 35.067 \\
\hline EHR & 10.545 & 20.919 & 29.100 & 33.171 & 34.940 \\
\hline$\%$ diff & 0.417 & 0.695 & 0.727 & 0.584 & 0.363 \\
\hline
\end{tabular}

German-UK wage differentials in relation to experience and tenure are widened when measured in terms of the EHR rather than the BHR.

Returning to the wage estimates in Tables 4 and 5, we find that education, which is measured by years of schooling, has the expected positive sign. Converting 
coefficients into rates of return in the usual $w^{8}{ }^{8}$, an additional year of schooling has a return of 8.4 per cent in the UK and 5.5 per cent in Germany when measured in relation to basic hourly rates. But the UK rate falls to 7.2 per cent and the German rate rises slightly to 5.6 per cent when overtime hours are taken into account. This implies that, for males, seemingly higher returns to schooling in the UK than in Germany in terms of the BHR are considerably reduced when the EHR measures are incorporated. Better-educated males in the UK provide more non-contractual hours to their employers than do German males, reducing their relative returns to education. A similar pattern emerges for females.

\section{DETERMINANTS OF OVERTIME Hours}

In this section, we estimate equations to explain paid and unpaid overtime by gender in our pooled dataset. We use a Tobit estimating procedure since many of the respondents work no overtime during the survey week. Our formulation is

$$
\begin{aligned}
\text { ohours } & =\mathbf{d}^{\prime} \mathbf{w}+\varepsilon \text { if } \mathbf{d}^{\prime} \mathbf{w}+\varepsilon>0 \\
& =0 \quad \text { if } \quad \mathbf{d}^{\prime} \mathbf{w}+\varepsilon \leq 0
\end{aligned}
$$

where overtime (ohours) is either paid or unpaid overtime, $\mathbf{d}$ is a vector of coefficients, $\mathbf{w}$ is a vector of explanatory variables and $\varepsilon$ is a disturbance term. The $\mathbf{w}$ vector consists of experience, the predicted wage, company size, managerial status, productivity residual, union as well as industry controls. The arguments for our specification link to our discussion in Section 2.

\footnotetext{
${ }^{8}$ If $\beta$ is the estimated coefficient, then the rate of return is given by $100 *(\exp (\beta)-1)$.
} 
The predicted wage is included for standard supply-side reasons in the paid overtime hours' equations. The fitted rather than the actual wage is used to avoid the endogeneity problem caused by joint determination of hours and wages. We include the standard hourly wage estimated from equation (3) and, following Lee (1978), this fitted wage is based on the economic variables but excludes the Heckman correction variable. Recall that, under Hypothesis 4 in Section 2, we postulated a positive wageunpaid hours relationship that links to gift exchange. As for company size, it would be expected that larger firms would more typically formalise work arrangements to reduce the transactions costs of their operations. It may also be the case that production in larger firms is relatively more constrained through the use of capital equipment and/or formal interactions with other personnel. With structured work arrangements, it is more likely that paid rather than unpaid overtime will be used as a response to unforeseen fluctuations in demand. In Section 2, we argued under Hypothesis 3 that team leaders might be willing to supply unpaid overtime hours. Both surveys inquire whether workers have managerial status in the sense that they control other workers, rather than having the occupational classification of manager. Given this leadership role, we would expect that such workers would be more likely to work unpaid overtime. Our arguments with respect to auctions (Hypothesis 2) suggest that unpaid work should be negatively associated with worker productivity. We cannot measure productivity directly from our surveys. Instead, we form a proxy - the productivity residual - using the deviation of the individual's standard hourly wage from the mean occupational wage. Results are shown in Tables 8 and 9 for males and females, respectively. 
The significantly negative predicted wage in the male paid overtime hours equations is consistent with an income effect. Equivalent female results are insignificant. However, the predicted wage is significantly positively related to unpaid overtime, for both males and females. These last results are consistent with the notion of gift exchange; workers respond to higher wages by providing more effort in terms of hours worked over and above paid-for hours. As predicted, company size in the UK is strongly positive in the paid hours equations, but either negative (in the case of females) or insignificant (males) in the unpaid hours equivalent. We postulated that large companies will have high transaction costs of organisation and communication and are less likely to deviate from paid-for work schedules. The sign and size of interactive dummies suggest that company size is not a significant factor in determining paid overtime hours in Germany. As in the UK, company size in the German unpaid hours' equation is insignificant while, for females, company size is negatively related to unpaid hours in both countries. Managerial status plays a consistently positive role in the male unpaid hours equations in the two countries, as predicted by our arguments relating to team leadership. This result also applies to UK females while the negative interactive term for German females more than offsets the UK coefficient. The productivity residual is significantly negative in all equations ${ }^{9}$, implying that lower productivity is associated with greater amounts of both paid and unpaid work. The idea of auction-bidding for jobs is consistent with this outcome. That it is associated with less paid overtime, may reflect selection on the part of employers when deciding which workers should be offered premium hours.

\footnotetext{
${ }^{9}$ There is no country interactive term associated with the productivity residual because the residual itself was estimated with country effects included.
} 
Table 8: Male Overtime Hours Equations

\begin{tabular}{|c|c|c|c|c|}
\hline & \multicolumn{2}{|c|}{ Paid Overtime } & \multicolumn{2}{|c|}{ Unpaid Overtime } \\
\hline & Coef. & t-stat & Coef. & t-stat \\
\hline Predicted wage & -8.998 & -5.981 & 18.190 & 9.911 \\
\hline Experience & 0.610 & 4.406 & -0.191 & -1.134 \\
\hline Experience $^{2}$ & -0.012 & -4.030 & 0.002 & 0.579 \\
\hline Germany*Experience & 0.177 & 1.005 & -0.334 & -1.231 \\
\hline Germany*Experience $^{2}$ & -0.005 & -1.204 & 0.008 & 1.407 \\
\hline Company Size & 3.975 & 3.827 & -2.214 & -1.760 \\
\hline Germany*Company Size & -3.846 & -2.897 & -2.278 & -1.100 \\
\hline Managerial Status & -2.368 & -2.400 & 4.789 & 5.085 \\
\hline Germany*Managerial Status & 4.710 & 3.151 & 3.268 & 2.139 \\
\hline Productivity residual & -1.241 & -1.930 & -1.503 & -2.061 \\
\hline Constant & 1.754 & 0.596 & -61.570 & -11.409 \\
\hline Number of observations & 3359 & & 3359 & \\
\hline Log Likelihood & -3617.361 & & -2751.638 & \\
\hline
\end{tabular}

(plus industry and marital status dummies)

Table 9: Female Overtime Hours Equations

\begin{tabular}{lcccc}
\hline & \multicolumn{2}{c}{ Paid Overtime } & \multicolumn{2}{c}{ Unpaid Overtime } \\
\hline & Coef. & t-stat & Coef. & t-stat \\
Predicted wage & -2.816 & -1.637 & 18.405 & 11.551 \\
Experience $^{2}$ & 0.294 & 1.810 & -0.108 & -0.815 \\
Experience $^{2}$ & -0.009 & -2.252 & 0.003 & 0.869 \\
Germany*Experience $^{2}$ & 0.226 & 1.038 & -0.748 & -2.989 \\
Germany*Experience $^{2}$ & -0.001 & -0.237 & 0.011 & 2.018 \\
Company Size $_{\text {Germany*Company Size }}$ & 5.179 & 4.467 & -4.297 & -4.637 \\
Managerial Status $_{\text {Germany*Managerial Status }}$ & -6.131 & -3.974 & -4.725 & -3.005 \\
Productivity residual & -0.459 & -0.382 & 1.939 & 2.389 \\
Constant $^{\text {Number of observations }}$ & -3.721 & 0.968 & -4.107 & -1.889 \\
Log Likelihood & -13.397 & -3.781 & -2.990 & -4.047 \\
\hline (plus industy and & 2907 & -3.344 & -42.005 & -8.956 \\
\hline
\end{tabular}

(plus industry and marital status dummies) 
Under Hypothesis 6, we postulate that unionism would be expected to be associated with low levels of unpaid overtime working. Due to the incompatibility of German UK data on unionisation, we were not able to include this variable in the analysis. Bell and Hart (1999a) provide strong UK evidence in support of the hypothesis, however.

\section{CONCLUSIONS}

Overtime working, both paid and unpaid, is more prevalent in the UK than in Germany. In both countries, paid overtime working is more common among manual workers, while unpaid overtime is more prevalent amongst managers and professionals. Males generally work more overtime than their female counterparts, except that female professionals in the UK work almost as much unpaid overtime as their male equivalents.

It turns out that differentiating between paid and unpaid overtime serves to form a more realistic picture of labour cost differences between Germany and the UK. The gap in basic hourly wage rates between the two countries is widened when effective hourly rates, which include the effects of unpaid hours, is used as the measure of direct hourly remuneration. This gap is particularly evident when measured with respect to accumulated work experience (see Tables 6 and 7). When added to nonwage labour cost differentials ${ }^{10}$, the UK's competitive labour cost advantage over Germany is greater than has previously been realised.

\footnotetext{
${ }^{10}$ In German industry in 1992, about 14 percent of total labour costs consisted of statutory welfare costs (EC Eurostat, Labour Cost Survey). Such costs comprise, mainly, industrial funding of state pensions, health and unemployment. Germany's labour market, like that of France (where non-statutory costs were 21.7 percent of total costs in 1992), suffers competitively from these add-on non-wage costs of employment. These percentages compare to 7.5 percent in the UK. Abraham (1999)
} 
At the outset, we offered a number of economic explanations as to why workers may be willing to offer unpaid hours of work. To the extent that such behaviour can be explained by rationale economic paradigms, it is perhaps surprising that two advanced industrialised countries - in close proximity and of relatively similar sizes - should display such quantitatively different amounts of unpaid work. Indirectly, our observations may reflect the relatively stronger, and more broadly based, collective bargaining institutions in Germany. Works Councils facilitate information transfer throughout German organisations in a way that is generally not matched in the British labour market. Unpaid work may be less commonly practiced on the German scene because it is more effectively monitored as between workers and management. This stated however, there are regularities between the two countries. We have shown that the significant determinants of paid and unpaid hours of work and related pay are similar in Germany and the UK. Again, differences tend to be ones of magnitude rather than direction.

Without doubt, when statistics become available, unpaid overtime will be found to feature significantly in the labour markets of other economies. On the basis of the two important European economies studied here, unpaid overtime turns out to be of roughly equal quantitative importance to paid overtime. Faced with historically high unemployment rates in recent decades, European policy makers in these and other

presents detailed inter-country breakdowns of labour costs in manufacturing in 1996 which pointedly reveal the high costs faced by German industry, in particular. It is in against this background that the overtime cost advantages in the UK compared to Germany become especially significant. 
economies have been keenly interested in the effects of cuts in working time on employment and worker compensation. As in the United States in earlier times, a large emphasis has been placed on work-sharing through reducing paid overtime among existing employees in order to create new jobs for the unemployed. The fact that significant numbers of workers, for a range of reasons, are prepared to work marginal hours for no pay serves seriously to complicate the assessment of such policy initiatives. 


\section{REFERENCES:}

Abraham, F (1999), “A policy perspective on European unemployment”, $\underline{\text { Scottish }}$ Journal of Political Economy, 46, 350-66.

Addison, J T, C Schnabel and J Wagner (1998), "Betriebsräte in der deutschen Industrie", in K Gerlach, O Hübler and W Meyer (eds.), Ökonomische Analyse betrieblicher Strukturen und Entwicklungen, Frankfurt: Campus.

Akerlof, G A (1982), "Labor contracts as partial gift exchange”, Quarterly Journal of Economics, 97, 543-69.

Bauer, T and K F Zimmermann (1999), “Overtime work and overtime compensation in Germany", Scottish Journal of Political Economy, 46, 419-36

Bell, D N F and R A Hart (1999a), “Unpaid Work”, Economica, 66, 271-290.

Bell, D N F and R A Hart (1999b), “Overtime Working in an Unregulated Labour Market", mimeo Department of Economics, University of Stirling, February

Bell, D N F and R A Hart (1998), "Working time in Great Britain, 1975-1994: evidence from the New Earnings Panel Data", Journal of the Royal Statistical Society (Series A) 161 Part 3, 327-348

Bulmahn, G and W Meyer (1998), "Ergaenzende Tarifvertragsregelungen zum Hannoveraner Firmenpanel", Diskussionspapier, 14, Department of Economics, University of Hannover.

Contensou, F and R Vranceanu (1999), Working Time: Theory and Policy Implications, London: Edward Elgar (forthcoming).

Gerlach, K and O Hübler (1987), "Personalnebenkosten, Beschäftigung und Arbeitsstunden aus neoklassischer und institutioneller Sicht”, in F Buttler, K Gerlach and R Schmieide (eds.), Arbeitsmarkt und Beschäftigung, Frankfurt: Campus, 291-331.

Hart, R A and R J Ruffell (1993), "The cost of overtime working in British production industries", Economica, 60, 183-201.

Hunt, J (1999), “Has work-sharing worked in Germany?”, Quarterly Journal of Economics, 114, 117-48.

Heckman, J (1979), "Sample selection bias as a specification error", Econometrica, 47, 153-61. 
Income Data Services (1997), Overtime, Study 671, London: Income Data Services Ltd.

Lee, L-F (1978), “Unionism and wage rates: a simultaneous equations model with qualitative and limited dependent variables", International Economic Review, $19,415-33$.

Murphy, K M and F Welch (1990), "Empirical age-earnings profiles", Journal of Labor Economics, 8, 203-29.

OECD Employment Outlook (1998, Chapter 5), "Working hours: latest trends and policy initiatives", Paris: OECD. 


\section{APPENDIX 1}

\section{UK LABOUR FORCE SURVEY}

The Labour Force Survey (LFS) is a survey of households living at private addresses in Great Britain. Its purpose is to provide information on the UK labour market which can then be used to develop, manage, evaluate and report on labour market policies. It is carried out by the Social Survey Division (SSD) of the Office for National Statistics (ONS) 1in Great Britain and by the Central Survey Unit of the Department of Finance and Personnel in Northern Ireland on behalf of $t$ he Department of Economic Development. It is a quarterly survey of around 40000 households that uses a panel design in which households remain part of the survey for five periods. It is only in the last wave that individuals are asked questions about their earnings. The data used here for 1993 are based on all households that experienced their "fifth wave" during 1993.

\section{GERMAN SOCIO-ECONOMIC PANEL}

The German Socio-Economic Panel (GSOEP) was started with the first wave in 1984. It is a representative longitudinal dataset on income, transfer payments, labour market experience, family composition, housing for individuals and families. In addition the dataset contains information on time spending, level of satisfaction, various aspects of life, hopes and fears, political involvement. Questions on the labour market include those to education and training, labour force participation, job changing, working time, wages, non-wage costs, tenure, position, firm size, distance between work place and home, unemployment.

The sample is representative of the whole population in Germany including foreigners. All household members 16 years and older are interviewed. The head of the household answers the household questionnaire which concentrates on housing quality, income, and transfer payments at the household.

The intial sample included 5921 households and 12245 individuals. From 1984 to 1989 the sample was restricted to West Germany. While attrition has reduced the sample, panel children who became older than 15 as well as new members of panel households have increased the sample. After eight waves the West German sample still included 9467 respondents. In 1990 separated samples for East and West Germany were conducted. The first wave for East Germany had 2179 households and 4453 individuals. With the beginning of 1991 we have a joint sample started with 6699 households and 13669 adult respondents. 


\section{IZA Discussion Papers}

\section{No. Author(s)}

31

C. M. Schmidt

32

S.- Å. Dahl

$\varnothing$. A. Nilsen

K. Vaage

33

A. Lindbeck

D. J. Snower

34

P. A. Puhani

D. A. Jaeger

A. Huff Stevens

36

C. Lauer

37

H. S. Buscher

C. Müller

M. E. Ward

P. J. Sloane
A. Lindbeck

D. J. Snower

40

S. M. Golder

T. Straubhaar

J. M. Orszag

D. J. Snower

42

D. S. Hamermesh

43

C. Belzil

J. Hansen

44

D. N. F. Bell

R. A. Hart

45

R. A. Hart

J. R. Malley

46
Title

Persistence and the German Unemployment Problem: Empirical Evidence on German Labor Market Flows

Work or Retirement? Exit Routes for Norwegian Elderly

Price Dynamics and Production Lags

Labour Mobility - An Adjustment Mechanism in Euroland?

Is Job Stability in the United States Falling? Reconciling Trends in the Current Population Survey and Panel Study of Income Dynamics

The Effects of European Economic and Monetary Union on Wage Behaviour

Exchange Rate Volatility Effects on the German Labour Market: A Survey of Recent Results and Extensions

Job Satisfaction within the Scottish Academic Profession

Multi-Task Learning and the Reorganization of Work

Empirical Findings on the Swiss Migration Experience

Anatomy of Policy Complementarities

The Changing Distribution of Job Satisfaction

Household Characteristics, Ability and Education:

Evidence from a Dynamic Expected Utility Model

Overtime Working in an Unregulated Labour Market

On the Cyclicality and Stability of Real Earnings 1

The Effects of Development on Migration: Theoretical Issues and New Empirical Evidence
Area Date

$1 / 7$ 2/99

$3 / 7$ 2/99 
Overtime Work and Overtime Compensation in

Unemployment and Labor-Market Reform: A

Ethnic German Migration After 1989 - Balance 1 and Perspectives

51 A. Barrett

P. J. O'Connell

Does Training Generally Work?

Self-Employment Decision of Immigrant

Entrepreneurs

\section{5 \\ L. Goerke}
A. Lindbeck

D. J. Snower

I. N. Gang

K. F. Zimmermann

T. Bauer

K. F. Zimmermann

D. J. DeVoretz

S. A. Laryea

60

C. Belzil

J. Hansen

61

R. Winkelmann

62
A. Thalmaier

63

M. Ward

64

M. Ward

65
H. Lehmann
J. Wadsworth
A. Acquisti

Value-added Tax versus Social Security Contributions

Centralized Bargaining and Reorganized Work: $\quad 1 / 5 \quad$ 9/99 Are they compatible?

Is Child like Parent?

Educational Attainment and Ethnic Origin

Occupational Mobility of Ethnic Migrants

Canadian Immigration Experience:

Any Lessons for Europe?

Subjective Discount Rates, Intergenerational

Bestimmungsgründe von Fehlzeiten: Welche

4



and the former Soviet Union to Germany: the Effects of Migrant Networks

Are Austrian Returns to Education Falling Over

Adjustment Dynamics and the Natural Rate: An 1

Endogenous Schooling and the Distribution of the Gender Wage Gap

Entrepreneurship from Scratch: Lessons on the Entry Decision into Self-Employment from Transition Economies

81 T. J. Hatton

The Netherlands: Old Emigrants - Young Immigrant Country

Migration, Migrants and Policy in the United 
Tenures that Shook the World: Worker Turnover in Russia, Poland and Britain

Identification and Estimation of Causal Effects of

$\begin{array}{ll}92 & \text { R. E. Wright } \\ 93 & \text { M. Lechner }\end{array}$

P. Cahuc A. Zylberberg

P. Cahuc

A. Zylberberg

97

A. Barrett

L. Husted

H. S. Nielsen

M. Rosholm

N. Smith

102 B. van der Klaauw

J. C. van Ours
The Rate of Return to Private Schooling

An Evaluation of Public-Sector-Sponsored Continuous Vocational Training Programs in East Germany

An Evaluation of Public Employment Programmes in the East German State of Sachsen-Anhalt

Job Protection, Minimum Wage and Unemployment 3

Redundancy Payments, Incomplete Labor Contracts, Unemployment and Welfare 
Matching Model with Uncertainty -

An Extension of Mortensen and Pissarides (1994)

Job Tenure of Two Cohorts of Young German Men

107 J. C. van Ours G. Ridder

J. Boone

J. C. van Ours

109 G. J. van den Berg

$B$. van der Klaauw

110 D. DeVoretz

C. Werner

V. Sorm

K. Terrell

\section{Bellmann}

T. Schank

113 R. Euwals

114 G. Brunello

A. Medio

115 A. Cigno

F. C. Rosati

116

C. Belzil

119 A. Lindbeck D. J. Snower

120 P. T. Pereira P. S. Martins
Fast Track or Failure: A Study of the Completion Rates of Graduate Students in Economics

Modeling Financial Incentives to Get Unemployed Back to Work

Combining Micro and Macro Unemployment

Duration Data

A Theory of Social Forces and Immigrant Second

Sectoral Restructuring and Labor Mobility:

A Comparative Look at the Czech Republic

Innovations, Wages and Demand for

Heterogeneous Labour: New Evidence from a

Matched Employer-Employee Data-Set

Do Mandatory Pensions Decrease Household

Savings? Evidence for the Netherlands

An Explanation of International Differences in

Education and Workplace Training

Why do Indian Children Work, and is it Bad for

7

Them?

Unemployment Insurance and Subsequent Job

7

Duration: Job Matching vs. Unobserved

Heterogeneity

IAB Employment Subsample 1975-1995.

Opportunities for Analysis Provided by the

Anonymised Subsample

Improving Nurse Retention in the British National Health Service: The Impact of Job Satisfaction on Intentions to Quit

The Division of Labor and the Market for

Organizations

Does Education Reduce Wage Inequality? 
122 D. Munich

J. Svejnar

K. Terrell

123 J. Hunt

124 R. T. Riphahn

125 F. Büchel

J. R. Frick

126 J. Fersterer

R. Winter-Ebmer

127 M. Karanassou

D. J. Snower

128

O. Ashenfelter

D. Ashmore

O. Deschênes

129 B. R. Chiswick

M. E. Hurst

130

G. Brunello

S. Comi

C. Lucifora

131 B. R. Chiswick

132

R. A. Hart

133

D. N. F. Bell

R. A. Hart

O. Hübler

W. Schwerdt
Returns to Human Capital under the Communist

4

Wage Grid and During the Transition to a Market

Economy

Why Do People Still Live in East Germany?

1

$3 / 00$

Rational Poverty or Poor Rationality? The Take-up

3

$3 / 00$

of Social Assistance Benefits

The Income Portfolio of Immigrants in Germany - $\quad 1 / 3 \quad 3 / 00$

Effects of Ethnic Origin and Assimilation. Or:

Who Gains from Income Re-Distribution?

Smoking, Discount Rates, and Returns to

$6 / 7 \quad 3 / 00$

Education
Characteristics of Unemployment Dynamics: The

Chain Reaction Approach

Do Unemployment Insurance Recipients Actively

Seek Work? Evidence From Randomized Trials in

Four U.S. States

The Employment, Unemployment and

Unemployment Compensation Benefits of

$1 / 3$

$3 / 00$

Immigrants

The Returns to Education in Italy: A New Look at $\quad 5 / 7 \quad 3 / 00$

the Evidence

Are Immigrants Favorably Self-Selected? An

Economic Analysis

Hours and Wages in the Depression: British $7 \quad 3 / 00$

Engineering, 1926-1938

Paid and Unpaid Overtime Working in Germany and 1

$3 / 00$

$3 / 00$

$3 / 00$

the UK 